Research Article

\title{
Evaluation of Selected Physicomechanical Properties of SFRC according to Different Standards
}

\author{
Tereza Komárková (D, Jaromír Láník, and Ondřej Anton \\ Faculty of Civil Engineering, Brno University of Technology, Veveři 95, Brno, Czech Republic \\ Correspondence should be addressed to Tereza Komárková; tereza.komarkova@vutbr.cz
}

Received 2 September 2017; Revised 31 January 2018; Accepted 4 March 2018; Published 14 May 2018

Academic Editor: Rishi Gupta

Copyright (C) 2018 Tereza Komárková et al. This is an open access article distributed under the Creative Commons Attribution License, which permits unrestricted use, distribution, and reproduction in any medium, provided the original work is properly cited.

\begin{abstract}
Steel fiber reinforced concretes are currently very popular, especially in the construction of industrial floors of warehouses and other halls with relatively large floor areas. However, it is important to mention that despite the rapid development of steel fiber reinforced concretes, the standards and regulations for their designing and testing have not been unified yet. This paper presents findings about the physicomechanical parameters of the steel fiber reinforced concretes manufactured by adding steel fibers into the truck mixer on the building site. The experimentally obtained results from the performed tests of tensile strength in bending according to various procedures are compared, and the suitability of the methods used is assessed according to these procedures.
\end{abstract}

\section{Introduction}

In the current building practice, steel fiber reinforced concrete is still mostly considered a new material. However, the idea of adding hard fibers to lower the undesirable natural fragility of the common building material is relatively old. The beginning of the 1960s marked a new period of a rising interest in reinforcing fragile building materials with fibers. First steel fiber reinforced concretes and glass fiber cement appeared. The various fiber technologies underwent rapid development, with ever-improving technical parameters, such as tensile strength and elasticity modulus (carbon fibers, aramid fibers, etc.) [1]. Various fibers were being experimentally added to concrete. The first three types to be employed in the building practice were steel wires, glass fibers, and polypropylene fibers. Their purpose was to improve the basic physicomechanical property of the composite, that is, to increase the tensile strength in bending at which the first crack caused by the dispersed fiber reinforcement appears, compared to the bending strength of common concrete. The dispersed fibers, however, can substantially increase the final strength, that is, the maximum load that the test specimen can sustain. However, this is preceded by a significant deformation, which in most practical applications exceeds the acceptable values, accompanied by an appearance of a number of very narrow cracks. The problems with strength lead to the promotion of steel fiber reinforced concretes focusing on their uniquely high toughness [2]. Steel fiber reinforced concretes usually display high-transformation work related to the ability to keep the useful load capacity even in large deformations. The toughness and the related properties are based on the fracture process of the composite, during which fibers are drawn and broken simultaneously with the increase in the number and width of cracks in the structure of the manufactured composite. Toughness, that is, the ability of steel fiber reinforced concrete to transfer load even after a relatively high deformation (compared to common concrete), is a useful property which is increasingly demanded but rarely appropriately specified. The even dispersion of fibers leads to the effect of spatial action of fibers in the structure of a composite and to stiffening of its whole structure [3]. As such, the fibers cannot be regarded as a reinforcement in the traditional sense of the word but rather as a stiffening element of the relatively fragile structure of plain concrete $[4,5]$. The initial optimistic predictions of the wide usage of steel fiber reinforced concretes assumed full-fledged interaction between the fibers and the structure of the original 
hardened common concrete. The interaction depends on cohesion between the fibers and the cement paste of the composite. There are many technologies for steel fiber manufacturing, which causes that they have various physical mechanical properties. Dimensions are also very important, such as length, thickness, or shape. These parameters are very important for required cohesion of fibers and cement matrix, which improves mechanical properties of steelreinforced concrete. A vast majority of fibers with a practical use in steel fiber reinforced concretes show very low natural cohesion with the hardened concrete [4]. The efficiency of dispersed fibers does not depend on the cohesion only [5]. In practice, all steel fiber reinforced concretes face the inevitable problems of the correct amount and concentration of fibers and their even dispersion and orientation $[5,6]$. Fiber-reinforced concrete with steel fibers gradually became commonplace in applications where it was required for the structural element to keep its loading capacity even after a considerable deformation, not to exhibit wide cracks, and, in the case of damage, not to fall apart for as long as possible. Its higher strength against impact load and other dynamic impacts proved to be also quite useful in such cases. This is reflected by a common use of steel fiber reinforced concretes for large industrial floors with heavy duty traffic or high load.

The insufficient homogeneity can be partially due to the manufacturing process of the fresh mixture or its processing. During the manufacturing process, the steel fibers, which determine the characteristics of the resulting steel fiber reinforced concrete as its principal component, must be dosed in the order required by the type of aggregate used. The diversity of fiber types results in the need to respect the recommended main principles determined on the basis of the long-term experience obtained from testing the manufacture of steel fiber reinforced concretes. All types of steel fibers must be added as the last ingredient of the mixture. Considering the variety of the existing machinery used for the manufacture of common concrete, which should also be used for the manufacture of common steel fiber reinforced concrete, it is always necessary to determine in advance that the machinery and given procedure of dosing fibers in the manufacture of fresh steel fiber reinforced concrete lead to achieving the necessary homogeneity of the mixture. A reliable path to manufacturing homogenous steel fiber reinforced concrete leads through the use of the machinery used in concrete plants, that is, compulsory mixers. The standard manufacture of concrete, done so far mostly in truck mixers, is not an optimal solution. Although the main principle for the use of steel fibers-to add steel fibers as the last component-is fulfilled, achieving homogeneity is difficult and at a cost of prolonging the time of mixing because the performance of truck mixers is considerably lower than that of compulsory mixers. In practice, where only the minimum amount of steel fibers per unit volume of fresh concrete is applied (as in the case of SFRC floors of the industrial halls), achieving the homogeneity of steel fiber reinforced concrete remains a pipe dream. The same can be said about its characteristics when applied, considering the influence of fibers on the hardening of the structure of cement composite. The relatively extensive usage of steel fiber reinforced concrete in floors leads to the emergence of new steel fiber manufacturers, new types of fibers, and thus a wide range of fibers which allows for choosing a suitable type of fiber for the required application.

Achieving broader knowledge of the properties of steel fiber reinforced concrete similar to that of other materials is only possible through a set of tests and experience obtained from real applications over a sufficiently long period of time. Only by connecting the material testing and the practice, we can achieve the defined objective. At the moment, it is possible to contribute to accelerating the aforementioned process by achieving a higher number of applications with a practical use of steel fiber reinforced concrete in a short time. One of the possibilities is a gradual unification of the testing procedures, which will lead to a unified assessment of the main characteristics of steel fiber reinforced concrete and to outputs allowing for a common procedure during preparations and implementation. For certain structures, the properties of steel fiber reinforced concretes can not only bring economic benefits but also be crucial for the implementation of the structures themselves. This applies even in the cases where steel fiber reinforced concrete is to be used in structures with traditional reinforcing-steel reinforcements or in prestressed structures. The method of testing the properties of steel fiber reinforced concretes, which slowly became a common part of structure designs, is currently not unified in terms of size of the test specimens, test arrangement, and their assessment. Fiber reinforced concrete with steel fibers must be included into building materials. The prerequisite for its use in concrete applications is having a good knowledge of the properties of the resulting composite obtained from mechanical tests with an appropriate assessment [7-14].

In this article, there are compared designed mixtures of steel fiber reinforced concrete, and they are tested according to standards common in Middle Europe. As it was mentioned before, resulting physicomechanical properties of the composite are affected by many factors. Authors focused on the test evaluation options according to described legislative standards with purpose of confirming of uniting methodology of determination bending strength, which is crucial for the steel fiber reinforced concrete classification.

\section{Experiment}

The experiment target was, according to the findings, to compare commonly used mixtures of the concrete of specified strength classes with concrete, where various amount of steel fibers were added, according to the flexural strength after cracks formations. The next target of the experiment was to compare the results evaluated according to various recommendations and standards for designing the steel fiber reinforced concrete constructions. Tests results were evaluated by three chosen recommendations for 
TABLE 1: Design of construction concrete with individual amounts of steel fibers [7].

\begin{tabular}{lc}
\hline Concrete & $\begin{array}{c}\text { Amount of fibers } \\
\left(\mathrm{kg} \mathrm{per} \mathrm{m}^{3}\right)\end{array}$ \\
\hline & - \\
C $16 / 20$ & 20 \\
& 25 \\
C $20 / 25$ & 30 \\
& - \\
& 20 \\
C $25 / 30$ & 25 \\
& 30 \\
C 30/37 & - \\
& 20 \\
& 25 \\
& 30 \\
& - \\
& 20 \\
\end{tabular}

construction designing and steel fiber reinforced concrete testing:

(1) Technické podmínky 1: Vláknobeton-Část 1 Zkoušení vláknobetonu: Vyhodnocení destruktivních zkoušek a stanovení charakteristického pracovního diagramu vláknobetonu pro navrhování vláknobetonových konstrukcí. hereinafter referred as TP FC 1-1 [15].

(2) According to the Directive Österreichische Vereinigung für Beton- und Bautechnik, hereinafter referred as ÖVBB [16].

(3) Performance classes of steel fiber reinforced concrete [17].

The concrete mixture was prepared in a laboratory. From each batch prepared, three test prisms with the dimensions of $150 \times 150 \times 700 \mathrm{~mm}$ were made for the tests of tensile strength in bending and for the determination of the residual strength after the appearance of cracks. 4 mixtures of fresh concrete with 4 variations of steel fibers amount, totally 48 test specimens, were made considering the required minimum amount of specimens for statistic evaluation and scale of experiment (Table 1).

Every fresh mixture was tested in consistency by the method of the slump test and flow test, and the air content was also tested. The specimens were cured and kept according to ČSN EN 12390-2 Testing hardened concrete-Part 2: Making and curing specimens for strength tests [18].

The steel fibers, from the German manufacturer KrampeHarex s.r.o., marked as DE50/0,1 N, were used in every mixture. The parameters of these fibers taken from the technical list are described in Table 2. Due to the requirement for pumpability of fresh concrete, there was chosen a procedure of dosing fibers in steps by $20 \mathrm{~kg}-25 \mathrm{~kg}-30 \mathrm{~kg}$ per $\mathrm{m}^{3}$ of fresh concrete.

For experimental testing, reference mixtures were used, which contained not only cement and aggregate but also fine slag (JMS), plasticizer, and power fly ash (Tables 3 and 4).
TABle 2: Properties of the steel fibers.

\begin{tabular}{lcccc}
\hline Fibers & $\begin{array}{c}\text { Length } \\
(\mathrm{mm})\end{array}$ & $\begin{array}{c}\text { Diameter } \\
(\mathrm{mm})\end{array}$ & Material & $\begin{array}{c}\text { Tensile } \\
\text { strength }\end{array}$ \\
\hline DE 50/1,0 N & $50 \pm 10 \%$ & $1.0 \pm 10 \%$ & C7D & $1100 \pm 15 \%$ \\
\hline
\end{tabular}

During the experiment, the manufactured test prisms with the dimensions of $150 \times 150 \times 700 \mathrm{~mm}$ were subjected to bending tests with the testing span of supports set to $600 \mathrm{~mm}$. The bending tests were carried out on a testing device which allowed for loading by a continuous controlled deformation up to the point of damage. The bending tests of prisms were always performed in four-point bending setup according to regulation TP FC 1-1 [15]. The four-point test setup was chosen on purpose so that the specimen is broken by bending in the critical cross section dependent on the distribution of steel fibers in the test specimen (Figure 1). The results of the test of steel fiber reinforced concrete prisms in four-point bending without a notch are mostly on the safe side. That was also the main reason why this type of arrangement of the test had been chosen. The bending tests were carried out on a mechanical testing press with a set range of $0-40 \mathrm{kN}$. The values of the strength parameters were read by a calibrated strain gauge. The rate of the controlled deformation was set to $0.04 \mathrm{~mm} / \mathrm{min}^{1}$, and the strain rate was constant during the test. The deflection of the test prism was read above the support with the use of a rigid steel measuring frame located on the upper surface of the test specimen, and the values were doubled afterwards. The reading was performed by a calibrated inductance trajectory sensor HBM with a measuring range of up to $100 \mathrm{~mm}$ and a sensitivity of $0.001 \mathrm{~mm}$. The output values were recorded with the data storage rate of $5 \mathrm{~Hz}$. The duration of the executed bending tests of standard steel fiber reinforced concrete prisms ranged from 45 to 60 minutes. In the case of reference concretes without steel fibers, the tests took from half to one third of the time. The values of deflection were considered as half of the value at the point of reading, and the values of monitored parameters (loadings and deflections) were rounded to 4 decimal places.

On the basis of the data obtained from the bending tests executed on the series of SFRC specimens, tensile strengths were calculated according to the individual regulations. The results are shown in Table 5 and Figures 2-11.

The values of the tensile strength in bending of the reference concrete mixtures tested according to the individual regulations do not show significant differences. When the individual values are compared, it is not possible to determine unambiguously which assessment approach is the most suitable because no marked differences were recorded during the evaluation, nor is it possible to observe any dependence between the individual approaches to the calculation of the tensile strength in bending.

By adding $20 \mathrm{~kg}$ of steel fibers into the reference concrete mixtures of the individual strength classes, no significant increase in the tensile strength in bending was achieved. The increase of the tensile strength depended only on the class of the concrete. 
TABLe 3: Composition of the referential concrete mixture in $\mathrm{kg}_{\text {per }} \mathrm{m}^{3}$ [19].

\begin{tabular}{|c|c|c|c|c|c|c|c|c|}
\hline Concrete & Cement CEM I 42,5 R & JMS & Fly ash & Aggregates $0-4$ & Aggregates 8-16 & Aggregates 11-22 & Amount of additive & Water \\
\hline C $16 / 20$ & 220 & 50 & 30 & 901 & 536 & 425 & 2.3 & 176 \\
\hline C $20 / 25$ & 240 & 50 & 30 & 880 & 536 & 425 & 2.5 & 177 \\
\hline C $25 / 30$ & 260 & 50 & 30 & 860 & 536 & 425 & 2.6 & 178 \\
\hline C $30 / 37$ & 280 & 50 & 30 & 855 & 546 & 435 & 2.1 & 170 \\
\hline
\end{tabular}

TABle 4: Composition of the steel fiber reinforced concrete mixtures in $\mathrm{kg}$ per $\mathrm{m}^{3}$.

\begin{tabular}{|c|c|c|c|c|c|c|c|c|c|}
\hline Concrete & $\begin{array}{c}\text { Amount of } \\
\text { fibers }\end{array}$ & $\begin{array}{c}\text { Cement CEM } \\
\text { I } 42,5 \mathrm{R} \\
\end{array}$ & JMS & $\begin{array}{l}\text { Fly } \\
\text { ash }\end{array}$ & $\begin{array}{c}\text { Aggregates } \\
0-4\end{array}$ & $\begin{array}{c}\text { Aggregates } \\
8-16 \\
\end{array}$ & $\begin{array}{c}\text { Aggregates } \\
11-22 \\
\end{array}$ & $\begin{array}{c}\text { Amount of } \\
\text { additive }\end{array}$ & Water \\
\hline \multirow{4}{*}{ C $16 / 20$} & 20 & \multirow{4}{*}{220} & \multirow{4}{*}{50} & \multirow{3}{*}{30} & \multirow{4}{*}{890} & \multirow{3}{*}{530} & 425 & \multirow{3}{*}{2.30} & 180 \\
\hline & 25 & & & & & & 420 & & 181 \\
\hline & 30 & & & & & & 415 & & 182 \\
\hline & 20 & & & \multirow{4}{*}{30} & & \multirow{3}{*}{530} & 425 & \multirow{4}{*}{2.47} & 181 \\
\hline \multirow[t]{3}{*}{ C $20 / 25$} & 25 & \multirow[t]{3}{*}{240} & \multirow[t]{3}{*}{50} & & \multirow[t]{3}{*}{870} & & 420 & & 182 \\
\hline & 30 & & & & & & 415 & & 183 \\
\hline & 20 & & & & & \multirow{3}{*}{530} & 425 & & 182 \\
\hline \multirow[t]{3}{*}{ C $25 / 30$} & 25 & \multirow[t]{3}{*}{260} & \multirow[t]{3}{*}{50} & \multirow[t]{3}{*}{30} & \multirow[t]{3}{*}{850} & & 420 & \multirow[t]{2}{*}{2.64} & 183 \\
\hline & 30 & & & & & & 415 & & 184 \\
\hline & 20 & & & & & \multirow{3}{*}{540} & 435 & \multirow{3}{*}{2.23} & 174 \\
\hline \multirow[t]{2}{*}{ C $30 / 37$} & 25 & \multirow[t]{2}{*}{280} & \multirow[t]{2}{*}{50} & \multirow[t]{2}{*}{30} & \multirow[t]{2}{*}{845} & & 430 & & 175 \\
\hline & 30 & & & & & & 425 & & 176 \\
\hline
\end{tabular}

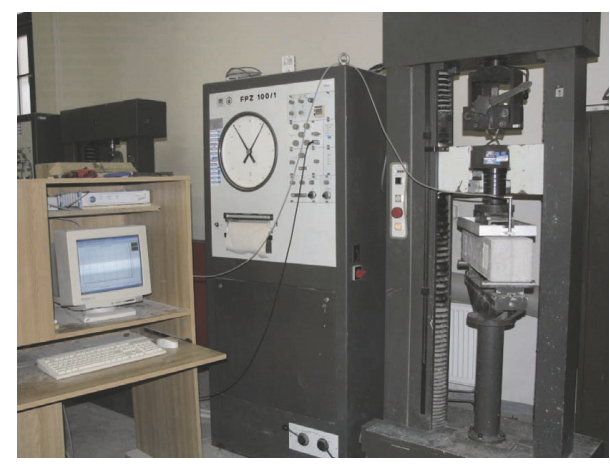

Figure 1: Process of the bending test of the SFRC prisms.

By adding $25 \mathrm{~kg}$ of steel fibers into the reference concrete mixtures of the individual strength classes, no significant change in the values of the tensile strength in bending was achieved. The values increase only in relation to the strength class of the concrete.

Admixture of $30 \mathrm{~kg}$ of steel fibers into the reference concrete mixtures caused a decrease in the tensile strength in bending in the strength class $C 25 / 30$. This fact could have been caused, for example, by exhaustion of the cement paste. Adding steel fibers caused an increase of the specific surface area which had to be bound to the cement paste, probably causing the exhaustion of the cement paste and the decrease of values.

Then the laboratory tests for residual bending strengths after crack formation were executed. The summary results of average values in MPa are stated in Table 6.

Calculation of the residual strength for reference concretes without dispersed steel reinforcement is rather misleading. The calculation results are strongly influenced by friction of aggregate in the emerging macrocrack. During the test prism loading controlled by deformation at low rates $\left(0.2 \mathrm{~mm} / \mathrm{min}^{1}\right)$, the friction of aggregate grains in the emerging microcrack is relatively high and "artificially" influences the values of residual strengths at larger deflections. In case the prism was loaded with a controlled force (hydraulic testing press), the values of residual forces would not be high, and the prism damage would suddenly occur at lower deflections. The phenomenon of grain friction in the macrocrack would be almost negligible, as is the case with common tests of tensile strength in bending executed according to the procedure described in ĆSN EN 12390-5 [20].

A dose of $20 \mathrm{~kg}$ of steel fibers per cubic meter of fresh concrete mixture is regarded as a minimum in most steel fiber reinforced concrete formulas in terms of the resulting composite keeping its ability to transfer load after the appearance of a microcrack. It is apparent from the results of the experiments executed that the dose of $20 \mathrm{~kg}$ of steel fibers is a borderline amount for ensuring sufficient residual strengths after the appearance of a crack in all the monitored strength classes. The individual assessment procedures showed different results depending on the method of recommended calculation. The lowest results were obtained when calculated according to the procedure described in the regulation TP FC 1-1 [15], where the minimum recommended residual strength after the emergence of a macrocrack is $0.4 \mathrm{~N} / \mathrm{mm}^{2}$. The best results were achieved when calculated according to the recommendation of the Performance classes of SFRC [17]. These differences were caused by different approaches of individual formulas to the calculation of residual strength.

By increasing the dose of steel fibers to $25 \mathrm{~kg} / \mathrm{m}^{3}$, a higher residual strength was achieved in all monitored strength classes. However, when evaluated according to TP FC 1-1, the resulting values of residual strength were on the boundary of applicability, especially for strength class C 
TABLE 5: Assessment of the tensile strength in bending according to the Austrian standard (ÖVB) [20], Performance classes of SFRC [6], and TP FC 1-1 [10] in MPa.

\begin{tabular}{llccc}
\hline $\begin{array}{l}\text { Concrete } \\
\text { mixtures }\end{array}$ & & ÖVBB & $\begin{array}{c}\text { Performance classes } \\
\text { of SFRC }\end{array}$ & TP FC 1-1 \\
\hline \multirow{4}{*}{ Referential } & C $16 / 20$ & 3.8 & 4.5 & 4.1 \\
& C $20 / 25$ & 4.9 & 5.0 & 5.1 \\
& C $25 / 30$ & 4.2 & 4.7 & 4.4 \\
& C $30 / 37$ & 5.0 & 4.8 & 5.0 \\
$20 \mathrm{~kg}$ & C $16 / 20$ & 3.8 & 4.2 & 4.0 \\
& C $20 / 25$ & 3.7 & 4.2 & 3.9 \\
& C $25 / 30$ & 4.6 & 5.1 & 4.8 \\
$25 \mathrm{~kg}$ & C $30 / 37$ & 4.9 & 4.8 & 5.0 \\
& C $16 / 20$ & 3.9 & 4.5 & 4.2 \\
& C $20 / 25$ & 3.9 & 3.9 & 4.0 \\
$30 \mathrm{~kg}$ & C $25 / 30$ & 4.3 & 4.2 & 4.5 \\
& C $30 / 37$ & 5.1 & 5.5 & 5.4 \\
& C $16 / 20$ & 3.8 & 3.7 & 4.0 \\
& C $20 / 25$ & 4.9 & 5.2 & 5.1 \\
& C $25 / 30$ & 3.8 & 3.9 & 3.8 \\
\hline
\end{tabular}

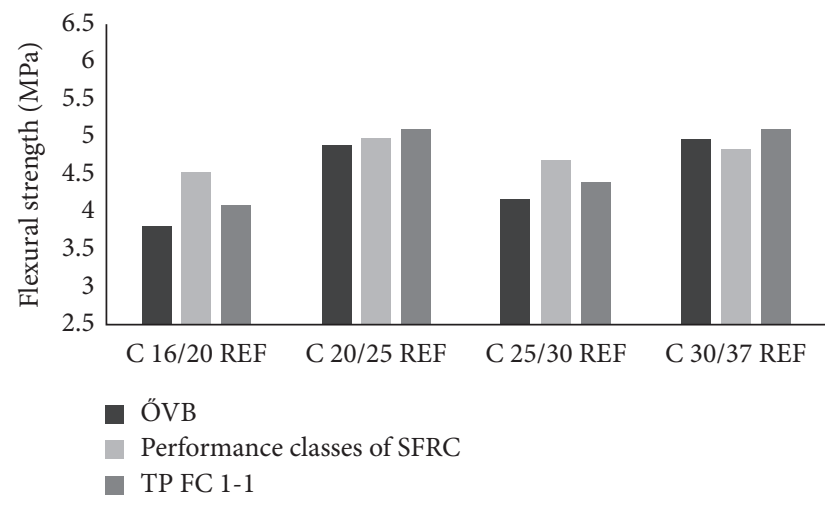

Figure 2: Bending strength of reference concrete mixtures.

20/25. In the case of strength class C $16 / 20$, a relatively significant increase in residual strength was observed when calculated according to the Performance classes of SFRC, where the performance calculation procedure involves a comparison between the resulting SFRC composite and the reference mixture.

Adding a dose of $30 \mathrm{~kg}$ of steel fibers into the individual reference mixtures caused an increase in the residual tensile strength in bending of the resulting steel fiber reinforced concrete. The most significant increase was observed in strength classes C 16/20 and C 20/25. The assessment of residual strengths according to the individual procedures showed that the highest benefit of the dose of steel fibers for the residual strength was found within strength class $\mathrm{C}$ $20 / 25$. The calculation results according to the procedure in TP FC 1-1 are again on the boundary of applicability in terms of the required residual strength after the emergence of a macrocrack. However, in strength class C 20/25, a significant increase in this strength was observed even when calculated according to the procedure in TP. The best results

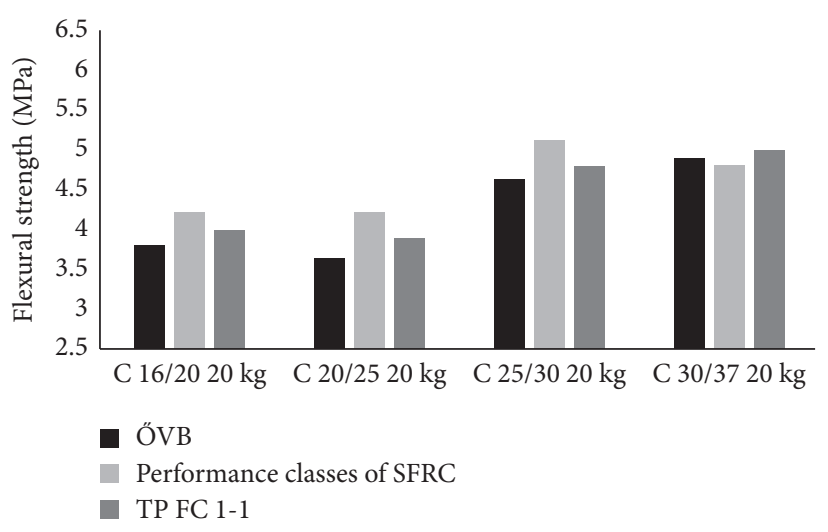

FigURE 3: Bending strength of SFRC-amount of fibers: $20 \mathrm{~kg} / \mathrm{m}^{3}$.

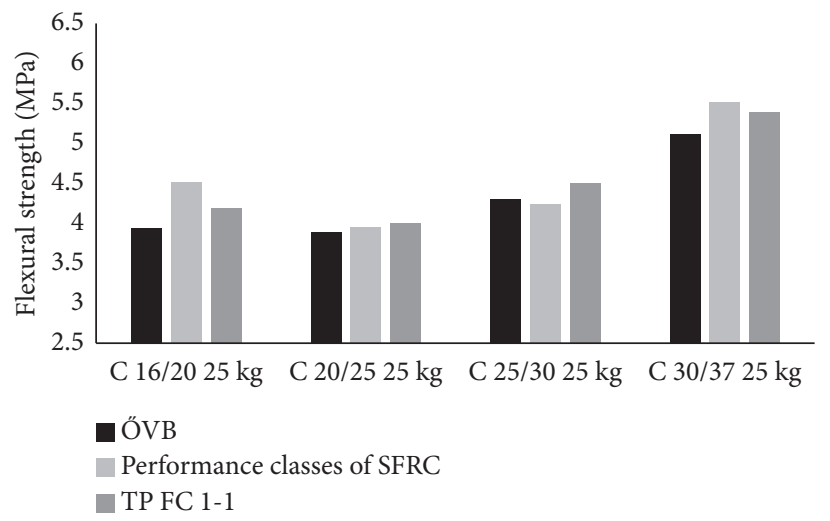

FIGURE 4: Bending strength of SFRC-amount of fibers: $25 \mathrm{~kg} / \mathrm{m}^{3}$.

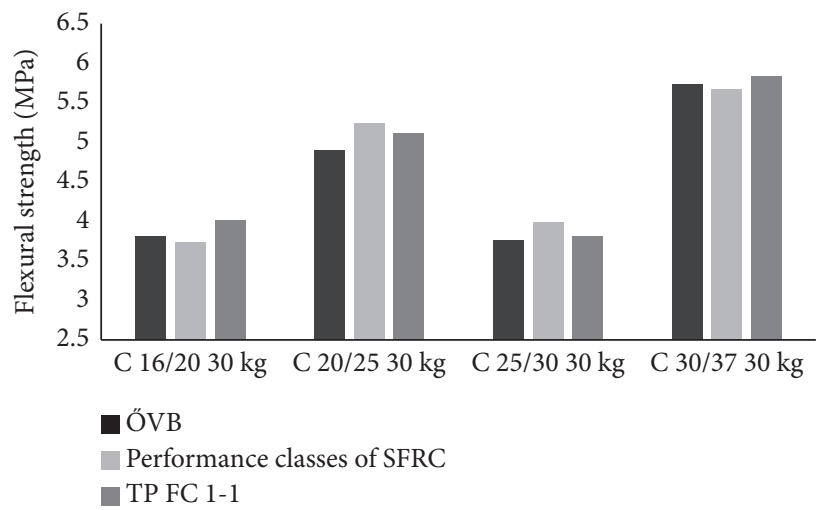

FIGURE 5: Bending strength of SFRC-amount of fibers: $30 \mathrm{~kg} / \mathrm{m}^{3}$.

of the residual tensile strength in bending were, again, achieved when the procedure described in the Performance classes of SFRC was used.

Table 7 shows the results of the individual calculations according to the selected procedures and recommendations for designing and assessment of manufactured SFRC composites on the basis of tests of tensile strength in bending performed on the manufactured standard test specimens after 28 days of maturing in a controlled environment. 


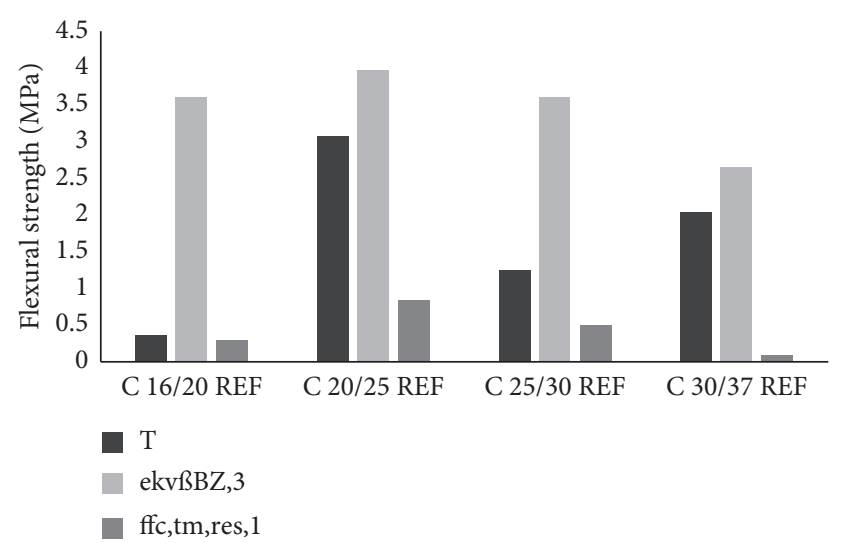

Figure 6: Residual tensile strength in bending at the moment of achieving a deflection of $3.5 \mathrm{~mm}$, reference mixture of common concrete.

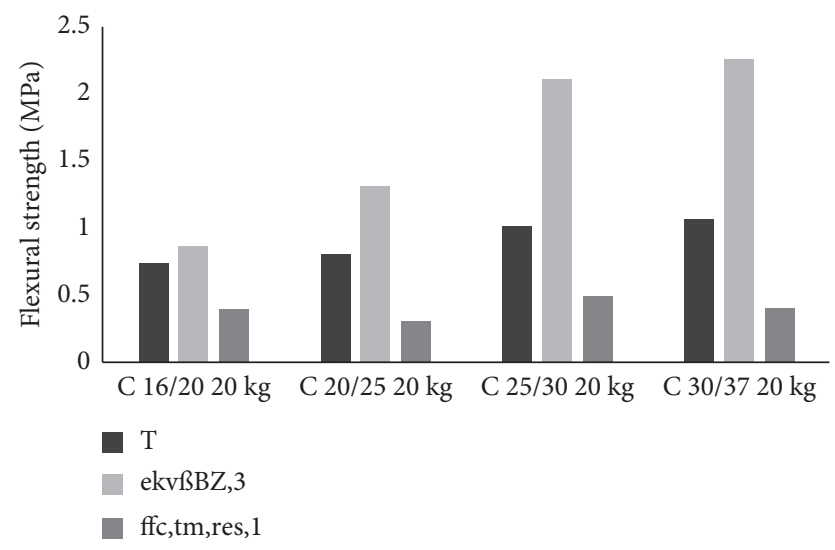

Figure 7: Residual tensile strengths in bending at the moment of achieving a deflection of $3.5 \mathrm{~mm}$, steel fiber reinforced concrete with a mass dose of $20 \mathrm{~kg} / \mathrm{m}^{3}$.

\section{Evaluation of the Performed Bending Tests according to a Simplified Calculation of Specific Fracture Energy}

Calculation of specific fracture energy for the individual tested sets of manufactured steel fiber reinforced concretes was driven by an effort to assess the influence of the amount of fibers on the energy necessary for the bending damage of the tested specimen to occur and the degree of influence of the given amount of fibers in the reference cement matrix on the bending damage. The results of calculations are summarized in the following table and included an evaluation of a standard deviation and a coefficient of variation for the individual sets. The values are only approximate because the specific fracture energy is calculated by a highly simplified procedure, and the ambient and other factors are disregarded in this case. The calculations are designed to compare the individual sets of test specimens with each other and cannot be used in more complex applications, such as MKP models (finite element method). If they were to be used for a modelling of the given matter by means of MKP methods, it would be necessary to use more complex procedures for determining the specific fracture energy and to approach experts on the given field (Table 8).

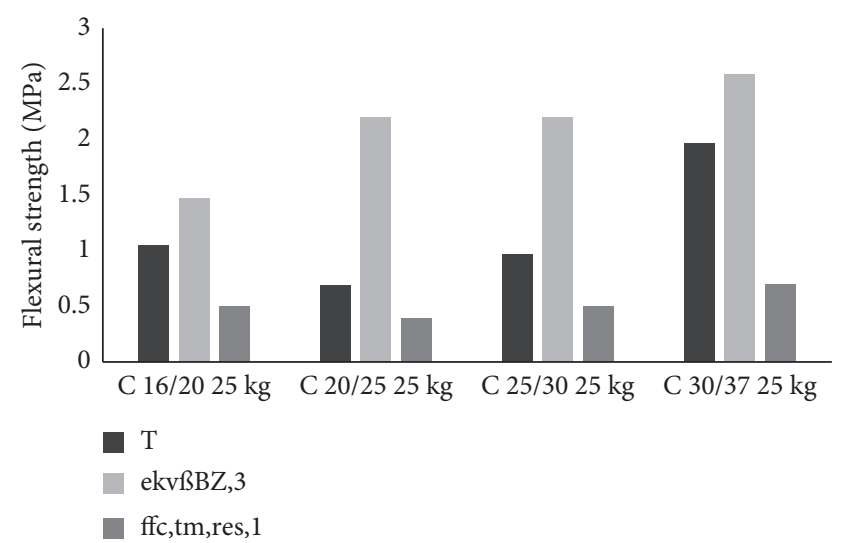

FIgURE 8: Residual tensile strength in bending at the moment of achieving a deflection of $3.5 \mathrm{~mm}$, steel fiber reinforced concrete with a dose weight of $25 \mathrm{~kg} / \mathrm{m}^{3}$.

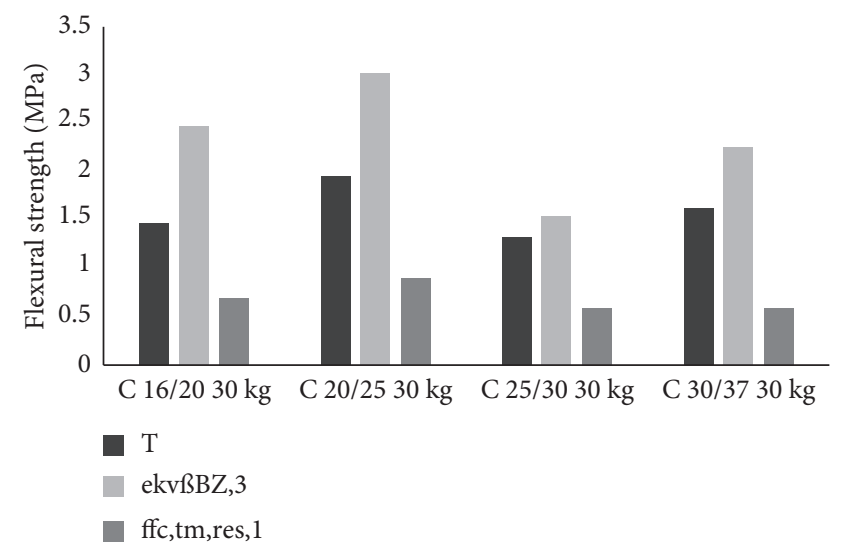

FIGURE 9: Residual tensile strengths in bending at the moment of achieving a deflection of $3.5 \mathrm{~mm}$, steel fiber reinforced concrete with a dose weight of $30 \mathrm{~kg} / \mathrm{m}^{3}$.

On the basis of the graphic representation of the results of simplified calculations of specific fracture energy, it is possible to conclude that the increasing content of steel fibers in concrete leads to an increase of fracture work, or fracture energy, compared to the reference mixture of common concrete. In some cases, it was possible to observe an opposite phenomenon where fibers decreased the value of the specific fracture energy compared to the reference concrete mixture. This phenomenon could have been caused, for example, by incorrect distribution of fibers in the reference concrete or by the loosening of the concrete due to admixture of steel fibers into a fresh mixture, potentially increasing the content of air pores in the hardened concrete. A higher content of air pores in the hardened concrete, acting as perfectly compressible nonhomogeneities in the structure of the composite, can influence the ability of the concrete composite to transmit.

Calculations of the standard deviation and the coefficient of variation when determining the specific fracture energy showed that increasing the amount of steel fibers in concrete causes an increase in the dispersion of measured values (tensile strength in bending). When higher doses of 


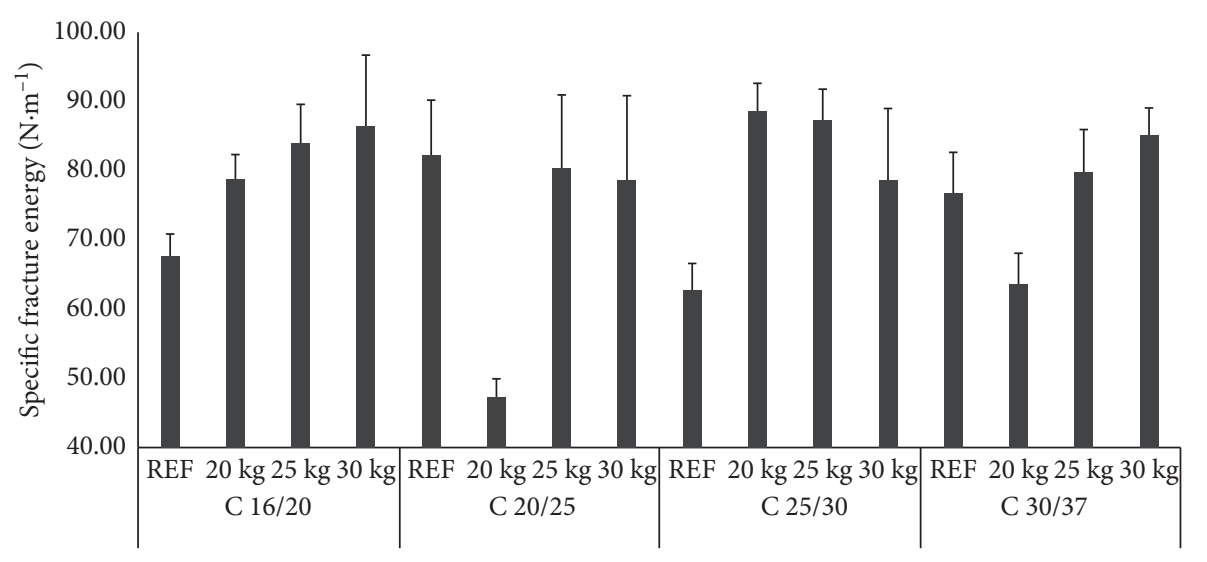

FIGURE 10: Results of calculations of specific fracture energy.

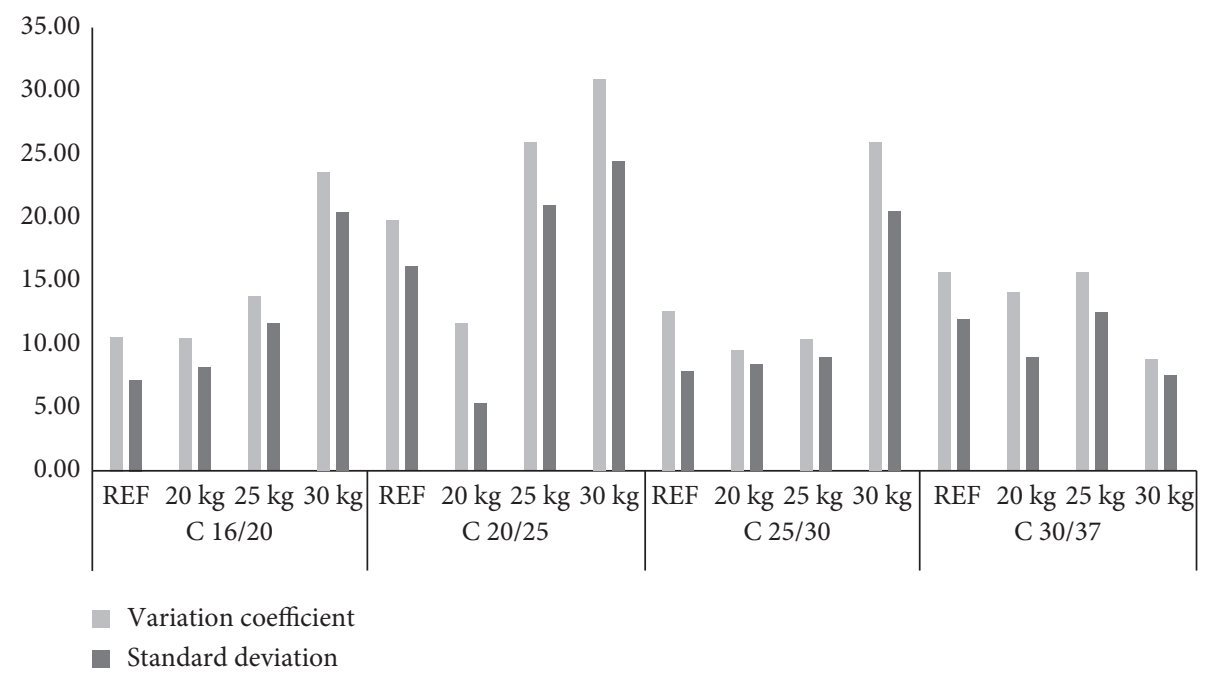

FIGURE 11: Representation of the coefficient of variation and standard deviation in the calculations of specific fracture energy from the working diagrams of the performed tests.

dispersed steel reinforcement $\left(30 \mathrm{~kg} / \mathrm{m}^{3}\right)$ are used, the distribution of fibers in the critical cross section is more random than in the case of lower doses. The dispersion of steel fibers when using higher doses is so significant that it considerably influences the dispersion of values in the bending tests where the critical cross section of the damage is not determined in advance, such as in the case of tests performed according to ČSN EN $14651+\mathrm{A} 1$ [21], where a three-point bending with a central notch is considered. When performing the bending tests of SFRC according to ČSN EN $14651+\mathrm{A} 1$ [21], the dispersion of values is lower even with higher doses of steel fibers. However, the question is which the method of damage testing is closer to reality and to the real influence of steel fibers in the manufactured cross section of, for example, floor panels in relation to the dosing of fibers to the truck mixer on the construction site.

\section{Conclusion}

During the bending tests of the manufactured steel fiber reinforced concretes, it was observed that the values of bending strength increase with the increasing amount of fibers. However, the increase of values was not as significant as expected. In relation to the increase in bending strengths, an increase in the residual strengths was observed. Based on the results of the performed tests, it is possible to say that the steel fiber reinforced concrete made from the basic mixture of the C 16/20 strength class with a $30 \mathrm{~kg}$ dose of steel fibers showed very similar properties in the residual tensile strength in bending as the SFRC one made from the basic mixture C $30 / 37$ with a $30 \mathrm{~kg}$ dose of steel fibers. The assessment of the executed bending tests of steel fiber reinforced concrete according to the three selected procedures (TP FC 1-1, Performance classes of SFRC, and Austrian standard for SFRC) showed that it is very important to choose a correct procedure according to which the tests of SFRC will be executed. The methods for determination of the tensile strength and residual tensile strength are rather different in the individual procedures and the calculation results vary significantly. The best results for residual strengths were always obtained using the procedure given by the "Performance classes of SFRC," while the residual strength 
TABle 6: Assessment of the residual tensile strength in bending at a deflection of $3.5 \mathrm{~mm}$ according to the Austrian Standard [16], Performance classes of SFRC [17], and TP FC 1-1 [15] in MPa.

\begin{tabular}{|c|c|c|c|c|}
\hline \multicolumn{2}{|c|}{ Concrete mixture } & $\begin{array}{c}\text { ÖVBB } \\
\mathrm{T}\end{array}$ & $\begin{array}{c}\text { Performance classes of SFRC } \\
\text { ekvß } \beta_{\mathrm{BZ}, 3}\end{array}$ & $\begin{array}{c}\text { TP FC 1-1 } \\
\mathrm{f}_{\mathrm{fc}, \mathrm{tm}, \mathrm{res}, 1}\end{array}$ \\
\hline \multirow{4}{*}{ REF } & C $16 / 20$ & 0.38 & 3.59 & 0.30 \\
\hline & C $20 / 25$ & 3.09 & 3.96 & 0.90 \\
\hline & C $25 / 30$ & 1.27 & 3.61 & 0.50 \\
\hline & C $30 / 37$ & 2.06 & 2.68 & 0.10 \\
\hline \multirow{4}{*}{$20 \mathrm{~kg}$} & C $16 / 20$ & 0.74 & 0.86 & 0.40 \\
\hline & C $20 / 25$ & 0.80 & 1.31 & 0.30 \\
\hline & C $25 / 30$ & 1.01 & 2.10 & 0.50 \\
\hline & C $30 / 37$ & 1.07 & 2.26 & 0.40 \\
\hline \multirow{4}{*}{$25 \mathrm{~kg}$} & C $16 / 20$ & 1.06 & 1.48 & 0.50 \\
\hline & C $20 / 25$ & 0.69 & 2.21 & 0.40 \\
\hline & C 25/30 & 0.97 & 2.21 & 0.50 \\
\hline & C $30 / 37$ & 1.98 & 2.60 & 0.70 \\
\hline \multirow{4}{*}{$30 \mathrm{~kg}$} & C $16 / 20$ & 1.48 & 2.48 & 0.70 \\
\hline & C $20 / 25$ & 1.95 & 3.03 & 0.90 \\
\hline & C $25 / 30$ & 1.33 & 1.54 & 0.60 \\
\hline & C $30 / 37$ & 1.63 & 2.26 & 0.60 \\
\hline
\end{tabular}

TABLE 7: Summary table with the results of assessment of the performed bending tests in MPa.

\begin{tabular}{|c|c|c|c|c|c|c|c|c|c|}
\hline \multirow{2}{*}{\multicolumn{2}{|c|}{ Identification }} & \multicolumn{3}{|c|}{ ÖVB } & \multicolumn{3}{|c|}{ Performance classes of SFRC } & \multicolumn{2}{|c|}{ TP FC 1-1 } \\
\hline & & $\mathrm{BZ}$ & G & $\mathrm{T}$ & $\beta_{\mathrm{BZ}}$ & $\mathrm{ekv} ß_{\mathrm{BZ}, 2}$ & $\mathrm{ekv} ß_{\mathrm{BZ}, 3}$ & $\mathrm{f}_{\mathrm{fc}, \mathrm{tm}, \mathrm{fl}}$ & $\mathrm{f}_{\mathrm{fc}, \mathrm{tm}, \mathrm{res}, 1}$ \\
\hline \multirow{4}{*}{ C $16 / 20$} & $20 \mathrm{~kg}$ & 3.82 & 1.73 & 0.74 & 4.22 & 1.73 & 0.86 & 4.00 & 0.40 \\
\hline & $25 \mathrm{~kg}$ & 3.94 & 1.98 & 1.06 & $4.52 \mathrm{~s}$ & 1.76 & 1.48 & 4.20 & 0.50 \\
\hline & $30 \mathrm{~kg}$ & 3.81 & 2.47 & 1.48 & 3.74 & 2.05 & 2.48 & 4.00 & 0.70 \\
\hline & REF & 3.82 & 1.12 & 0.38 & 4.53 & 3.27 & 3.59 & 4.10 & 0.30 \\
\hline \multirow{4}{*}{ C $20 / 25$} & $20 \mathrm{~kg}$ & 3.66 & 1.47 & 0.80 & 4.22 & 1.74 & 1.31 & 3.90 & 0.30 \\
\hline & $25 \mathrm{~kg}$ & 3.90 & 2.55 & 0.69 & 3.95 & 2.21 & 2.21 & 4.00 & 0.40 \\
\hline & $30 \mathrm{~kg}$ & 4.88 & 2.84 & 1.95 & 5.23 & 2.36 & 3.03 & 5.10 & 0.90 \\
\hline & REF & 4.91 & 4.81 & 3.09 & 5.00 & 3.65 & 3.96 & 5.10 & 0.90 \\
\hline \multirow{4}{*}{ C $25 / 30$} & $20 \mathrm{~kg}$ & 4.63 & 2.22 & 1.01 & 5.13 & 2.41 & 2.10 & 4.80 & 0.50 \\
\hline & $25 \mathrm{~kg}$ & 4.31 & 2.05 & 0.97 & 4.24 & 2.36 & 2.21 & 4.50 & 0.50 \\
\hline & $30 \mathrm{~kg}$ & 3.75 & 2.41 & 1.33 & 3.98 & 1.64 & 1.54 & 3.80 & 0.60 \\
\hline & REF & 4.18 & 3.77 & 1.27 & 4.70 & 3.32 & 3.61 & 4.40 & 0.50 \\
\hline \multirow{4}{*}{ C $30 / 37$} & $20 \mathrm{~kg}$ & 4.90 & 2.94 & 1.07 & 4.81 & 2.25 & 2.26 & 5.00 & 0.40 \\
\hline & $25 \mathrm{~kg}$ & 5.12 & 3.05 & 1.98 & 5.51 & 254 & 2.60 & 5.40 & 0.70 \\
\hline & $30 \mathrm{~kg}$ & 5.71 & 3.15 & 1.63 & 5.64 & 2.48 & 2.26 & 5.80 & 0.60 \\
\hline & REF & 4.99 & 4.72 & 2.06 & 4.84 & 3.34 & 2.68 & 5.10 & 0.10 \\
\hline
\end{tabular}

TABLE 8: Results of calculations of specific fracture energy from the working diagrams in $\mathrm{N} / \mathrm{m}$.

\begin{tabular}{|c|c|c|c|c|c|c|c|}
\hline \multicolumn{2}{|c|}{ Identification } & Specimen A & Specimen B & Specimen $\mathrm{C}$ & Average value & Standard deviation & Coefficient of variation \\
\hline \multirow{4}{*}{ C $16 / 20$} & REF & 74.79 & 57.46 & 69.66 & 67.30 & 7.27 & 10.80 \\
\hline & $20 \mathrm{~kg}$ & 86.95 & 80.82 & 67.15 & 78.31 & 8.28 & 10.57 \\
\hline & $25 \mathrm{~kg}$ & 100.19 & 79.12 & 72.79 & 84.03 & 11.71 & 13.94 \\
\hline & $30 \mathrm{~kg}$ & 64.69 & 113.95 & 81.11 & 86.582 & 20.48 & 23.65 \\
\hline \multirow{4}{*}{ C $20 / 25$} & REF & 83.00 & 61.93 & 101.94 & 82.29 & 16.34 & 19.86 \\
\hline & $20 \mathrm{~kg}$ & 55.23 & 42.96 & 43.96 & 47.38 & 5.56 & 11.74 \\
\hline & $25 \mathrm{~kg}$ & 108.99 & 58.81 & 74.25 & 80.68 & 20.98 & 26.01 \\
\hline & $30 \mathrm{~kg}$ & 66.65 & 56.75 & 113.04 & 78.81 & 24.54 & 31.13 \\
\hline \multirow{4}{*}{ C $25 / 30$} & REF & 59.90 & 73.84 & 54.92 & 62.89 & 8.01 & 12.73 \\
\hline & $20 \mathrm{~kg}$ & 79.79 & 100.24 & 85.84 & 88.62 & 8.58 & 9.68 \\
\hline & $25 \mathrm{~kg}$ & 78.03 & 99.94 & 84.55 & 87.51 & 9.19 & 10.50 \\
\hline & $30 \mathrm{~kg}$ & 73.11 & 106.36 & 56.96 & 78.81 & 20.57 & 26.10 \\
\hline \multirow{4}{*}{ C $30 / 37$} & REF & 80.04 & 60.69 & 89.89 & 76.87 & 12.13 & 15.78 \\
\hline & $20 \mathrm{~kg}$ & 53.54 & 62.11 & 75.59 & 63.75 & 9.08 & 14.24 \\
\hline & $25 \mathrm{~kg}$ & 88.52 & 62.12 & 89.04 & 79.89 & 12.57 & 15.73 \\
\hline & $30 \mathrm{~kg}$ & 79.60 & 96.21 & 80.41 & 85.41 & 7.65 & 8.95 \\
\hline
\end{tabular}


calculations according to the recommendations of the Austrian standard for SFRC also lead to relatively good results. The results of calculations of residual strengths of SFRC according to the Czech Technical Regulation TP FC 1-1 were relatively low, often on the boundary of usability of the manufactured composite in the given application. These differences were caused by different approaches to the determination of residual strengths based on the bending tests. The foreign procedures perform calculations either on the basis of performance, where the benefit of steel fibers is assessed by comparing a reference mixture of common concrete and the same mixture with the steel fibers added, or by means of an "energetic" approach in which the area below the curve of the working diagram of the SFRC bending test up to the conventional deformation is evaluated. It is thus very important to know which approach to the assessment of residual strength of SFRC to choose so that the resulting composite has the required properties. If someone specifies, or guarantees, the properties or steel fiber reinforced concrete, it is necessary to know according to which regulation and procedure these properties, especially residual strength, were calculated. From the results achieved with the manufactured steel fiber reinforced concretes in the experimental part, it is apparent that the individual procedures and recommendations for SFRC should not be combined because the results deemed satisfactory according to one procedure but can be nonsatisfactory when calculated according to another. Based on the results, the authors recommend the procedure according to the TP FC 1-1.

\section{Conflicts of Interest}

The authors declare that they have no conflicts of interest.

\section{Acknowledgments}

This paper has been worked out under the Project no. LO1408 "AdMaS UP-Advanced Materials, Structures and Technologies," supported by Ministry of Education, Youth and Sports under the "National Sustainability Programme I."

\section{References}

[1] T. F. Flory, J. Hearle, H. Mckenna, and M. Parsey, "About 75 years of synthetic fiber rope history," in Proceedings of the OCEANS MTS/IEEE Conference, Washington, DC, USA, October 2015.

[2] T. Simões, H. Costa, D. Dias-da-Costa, and E. Júlio, "Influence of fibres on the mechanical behaviour of fibre reinforced concrete matrixes," Construction and Building Materials, vol. 137, no. 1, pp. 548-556, 2017.

[3] G. Appa Rao and A. Sreenivasa Rao, "Toughness indices of steel fiber reinforced concrete under mode II loading," Materials and Structures, vol. 42, no. 9, pp. 1173-1184, 2009.

[4] V. Veselý, J. Vodička, J. Vašková, and J. Krátký, "Tests of structural fibre concrete," in Beton: Technologie, Konstrukce, Sanace, pp. 43-47, Czech Concrete Society, Praha, Czech Republic, 2010.

[5] R. Gettu, D. R. Gardner, H. Saldívar, and B. E. Barragán, "Study of the distribution and orientation of fibers in SFRC specimens," Materials and Structures, vol. 38, no. 1, pp. 31-37, 2005.

[6] P. J. M. Bartoš, "Fibre reinforced concrete," in Beton: Technologie, Konstrukce, Sanace, pp. 69-77, Czech Concrete Society, Praha, Czech Republic, 2012.

[7] J. Vodička, V. Veselý, K. Kolář, and J. Krátký, "Fibre concrete in practice," in Beton: Technologie, Konstrukce, Sanace, pp. 53-55, Czech Concrete Society, Praha, Czech Republic, 2010.

[8] A. Blanco, P. Pujadas, A. de la Fuente, S. H. P. Cavalaro, and A. Aguado, "Assessment of the fibre orientation factor in SFRC slabs," Composites Part B: Engineering, vol. 68, no. 1, pp. 343-354, 2015.

[9] P. Stähli, R. Custer, and J. G. M van Mier, "On flow properties, fibre distribution, fibre orientation and flexural behaviour of FRC," Materials and Structures, vol. 41, no. 1, pp. 189-196, 2008.

[10] P. Pytlík, Technologie Betonu, VUTIUM, Brno, Czech Republic, 2000.

[11] J. Vodička, V. Veselý, and J. Krátký, "Specifics of fibre concrete technology," in Beton: Technologie, Konstrukce, Sanace, pp. 3842, Czech Concrete Society, Praha, Czech Republic, 2010.

[12] J. Krátký, J. Vodička, and J. Vašková, “Design of fibre concrete structural elements," in Beton: Technologie, Konstrukce, Sanace, pp. 87-89, Czech Concrete Society, Praha, Czech Republic, 2010.

[13] J. Vašková, "Experimental verifying of fibre concrete elements behaviour," in Beton: Technologie, Konstrukce, Sanace, pp. 74-78, Czech Concrete Society, Praha, Czech Republic, 2010.

[14] J. Štoller and E. Zezulová, "The application of fibre reinforced concrete for protective shelter from auxiliary material," Key Engineering Materials, vol. 755, pp. 374-381, 2017.

[15] TP FC 1-1, Technické podmínky 1: Vláknobeton - Část 1 Zkoušení vláknobetonu: Vyhodnocení Destruktivních Zkoušek a Stanovení Charakteristického Pracovního Diagramu Vláknobetonu pro Navrhování Vláknobetonových Konstrukcí, Českomoravský Beton, a.s., Praha, Czech Republic, 2007.

[16] ÖVBB-Richtlinie Faserbeton, Österreichische Vereinigung für Beton und Bautechnik: Faserbeton, Austrian Structural Engineering Association, Vienna, Austria, 2008.

[17] H. Falkner, M. Teutsch, and H. Klinkert, Massivbau und Brandschutz: Leistungsklassen von Stahlfaserbeton, IBMB, Braunschweig, Germany, 1999.

[18] ČSN EN 12390-2, Testing Hardened Concrete: Part 2: Making and Curing Specimens for Strength Tests, Czech Office for Standards, Metrology and Testing, Praha, Czech Republic, 2009.

[19] T. Komárková, J. Láník, and P. Dvořák, "Influence of dispersed reinforcement on the physico-mechanical properties of the SFRC," Key Engineering Materials, vol. 755, pp. 75-81, 2017.

[20] ČSN EN 12390-5, Testing Hardened Concrete-Part 5: Flexural Strength of Test Specimens, Czech Office for Standards, Metrology and Testing, Praha, Czech Republic, 2009.

[21] ČSN EN $14651+$ A1, Test Method for Metallic Fibered Concrete: Measuring the Flexural Tensile Strength (Limit of Proportionality (LOP), Residual), Czech Office for Standards, Metrology and Testing, Praha, Czech Republic, 2008. 


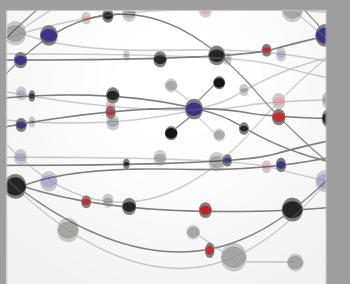

The Scientific World Journal
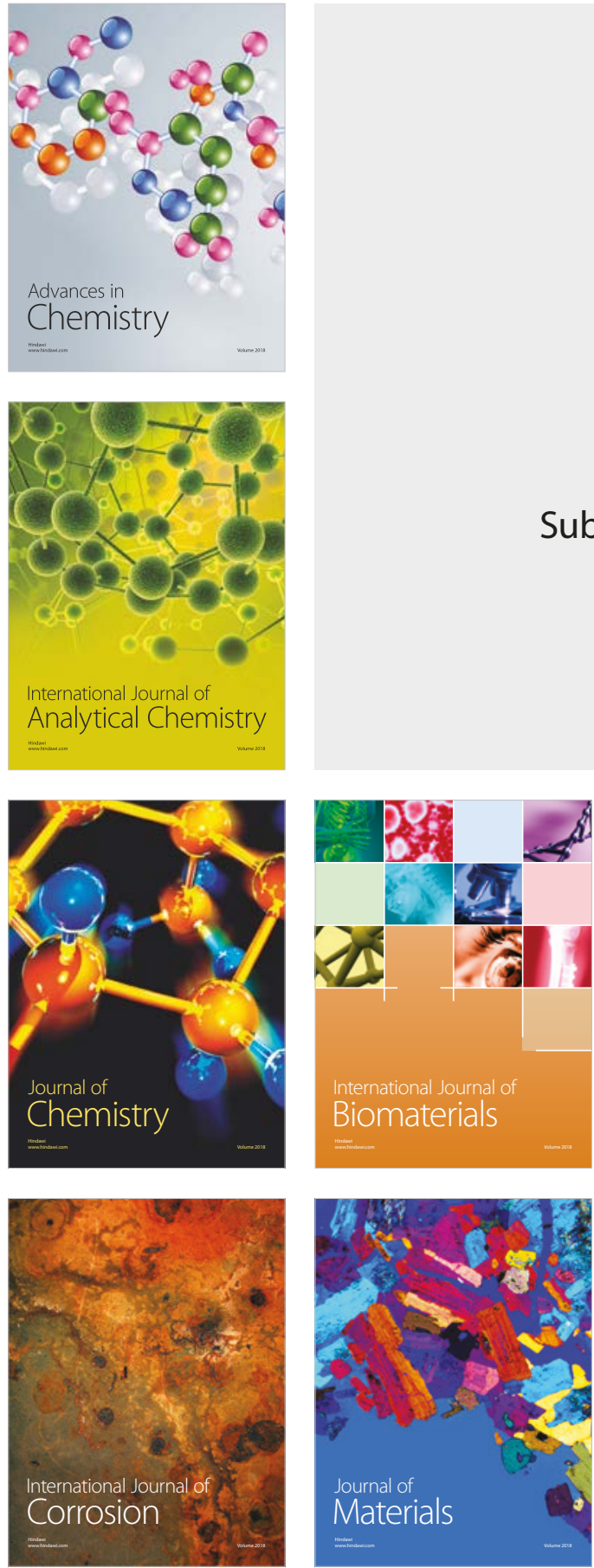

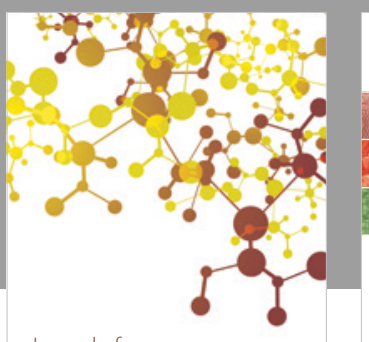

Journal of

Applied Chemistry
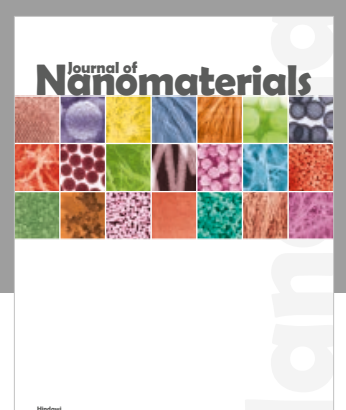

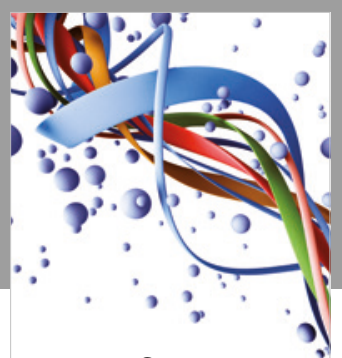

Scientifica

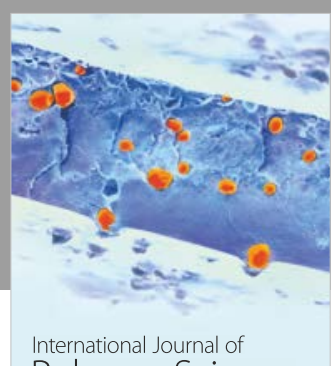

Polymer Science

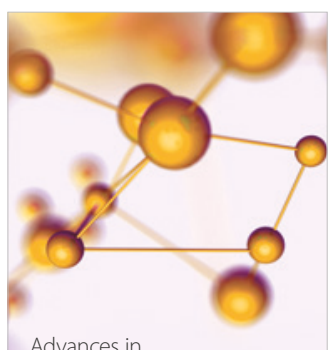

Physical Chemistry
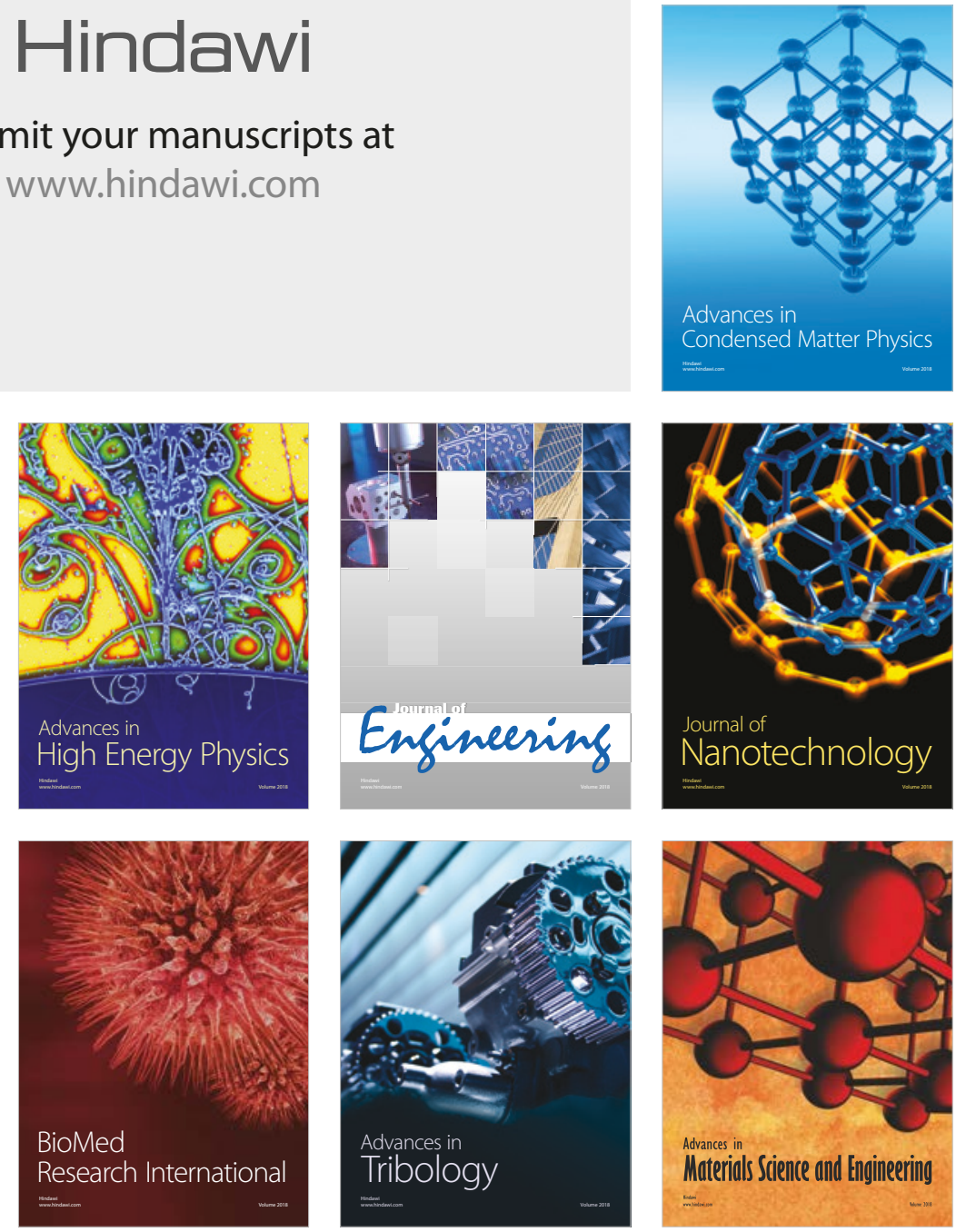